\title{
INFLUENCE OF GROWTH REGULATORS ON SHOOT PROLIFERATION AND PLANTLET PRODUCTION FROM SHOOT TIPS OF BANANA
}

\author{
S. Rehana ${ }^{1}$, M. S. Alam ${ }^{2}$, K. S. Islam ${ }^{3}$ and M. A. Samad ${ }^{4}$ \\ Bangladesh Agricultural University, Mymensingh-2202, Bangladesh
}

\begin{abstract}
The effect of BAP and IBA on in vitro regeneration of four banana cultivars viz. 'Amritsagar', 'Seeded banana', 'Sabri' and 'Anajee' was studied. The response of single shoot regeneration from shoot tips of four banana cultivars at different concentrations of BAP was found to be different. The cultivar 'Amritsagar' produced the highest percentage $(60 \%)$ of single shoot at $4.0 \mathrm{mg} / 1 \mathrm{BAP}$ within 10-15 days. The cultivar 'Sabri' and 'Anajee' produced lower percentage of single shoots. Rates of shoot multiplication of 'Amritsagar', 'Sabri', and 'Anajee' were 6-7 plantlets/explant, 2-4 plantlets/explant, and 2 plantlets/explant, respectively on medium containing $4.0 \mathrm{mg} / 1 \mathrm{BAP}$ after 30 days of culture. But in subsequent subculture, on the same medium, 'Amritsagar' produced the highest number of plantlets ( 9 plantlets/explant) within the same period of time. The best root formation in multiplied shoots of 'Amritsagar' was found on MS medium containing $2.0 \mathrm{mg} / 1 \mathrm{IBA}$ after 15 days of culture. All the in vitro cultured banana plantlets of 'Amritsagar' survived when weaned to ex vitro conditions on soil.
\end{abstract}

Key words : Banana, Cultivar, In vitro, BAP, IBA, Micropropagation

\section{INTRODUCTION}

Banana is one of the important and popular fruit in Bangladesh for its year round availability, abundant production and high acceptability as a fruit to the consumers. Banana is a rich source of carbohydrate and minerals such as $\mathrm{Ca}, \mathrm{Mg}, \mathrm{Na}, \mathrm{P}$ and $\mathrm{K}$. It is particularly rich in vitamin-C and also contains significant amounts of several other vitamins (INIBAP, 1987). Conventional breeding methods rely on the combination of useful traits through hybridization and are thus dependent on the productive mechanism of a crop species. Many of the existing crop cultivars are bred from common ancestral species and are thus narrowing genetic base causing vulnerable to biotic and abiotic stresses. Induction of genetic variability for the production of novel fruit with higher yielding resistant to pest and diseases, ability to adapt in new climates and extreme

\footnotetext{
${ }^{1}$ Biotechnology and Genetic Engineering Discipline, Khulna University, Khulna, Bangladesh

2 Department of Genetics and Plant Breeding, Bangladesh Agricultural University, Mymensingh, Bangladesh

3 Intercooperation AFIP Project, Gulshan-2, Dhaka, Bangladesh

4 Bangladesh Institute of Nuclear Agriculture, Mymensingh, Bangladesh
} 
environmental variables is also required to be evolved (Thorpe and Biondi, 1984; Bajaj, 1986). The primary goal of plant cell culture research is crop improvement (Evans et al., 1981). Using in vitro technique, a new cultivar can be made commercially available more quickly, it can also be used to obtain mutants and for setting up gene banks (Pierik, 1975; Assche, 1983; Kunneman-kooij, 1984). The in vitro shoot tip culture is used not only for a rapid propagation (Harris and Stenvenson, 1979) but also to eradicate virus and some other important disease (Stone, 1968). Banana is propagated vegetatively from massive underground corm with highly compressed internode (Barker and Steward, 1962). Suckers of banana are infected with various diseases such as banana bunchy top and panama, which are carried over through generations and affect the yield. Thus the productivity of fruits decreases and finally the yield becomes very poor and static. Apical meristem culture offers an efficient method for rapid clonal propagation, production of pathogen free material and germplasm preservation in plants (Cronauer and Krikorian, 1984; Hwang et al., 1984; Wong, 1986). Plant growth regulators especially cytokinin (BAP) helps in shoot multiplication and Auxin (IBA) helps in rooting of multiplied shoots. However, requirements of cytokinin and auxin depend to the variety and culture conditions used (Cronauer and Krikorian, 1984). Thus, the present study was undertaken to assess the effect of different doses of BAP and IBA on in vitro regeneration and rooting of four commercially important varieties/cultivars of banana in Bangladesh.

\section{MATERIALS AND METHODS}

\section{Plant materials}

The experimental materials such as Amritsagar (Genotype AAA), Sabri (Genotype AAA), Anajee (Genotype ABB), Seeded banana (Genotype $B B$ ) were collected from the neighboring villages of Bangladesh Agricultural University, Mymensingh and used as the source materials for obtaining meristem tip.

\section{Preparation of explants}

The shoot tips were initially prepared by removing the outer layers of tissues from suckers with a clean knife. Then they were taken in a beaker and were sterilized with 70 $\%$ ethanol for one minute. Then they were washed 3 times with sterile distilled water and finally surface disinfected inside the laminar airflow cabinet with $0.1 \% \mathrm{HgCl}_{2}$ solution for 15 minutes followed by washing thrice with sterile distilled water.

\section{Culture media and experimental detail}

The explants were placed on MS (Murasige and Skoog, 1962) medium supplemented with five concentrations of BAP $(0,2,4,6,8 \mathrm{mg} / \mathrm{l})$. Ten explants were cultured per treatment. All cultures were incubated at $25 \pm 2^{\circ} \mathrm{C}$. A 16-hour light period was maintained with a light intensity of 2000 lux for the growth and development of the cultures. The $\mathrm{pH}$ of the medium was adjusted to 58 . The medium was sterilized by autoclaving at 15 -psi pressure and $121^{\circ} \mathrm{C}$ temperature for 20 minutes. The materials were subcultured at 30 days interval in the same fresh medium to produce multiple shoots. 
Total numbers of shoots/explant and average length of shoots were recorded up to $4^{\text {th }}$ subculture. The regenerated shoots were cultured in rooting medium consisting of MS (Murasige and Skoog, 1962) basal salts supplemented with different concentrations of IBA $(0,1,2,3$ and $4 \mathrm{mg} / \mathrm{l})$. Days to root induction, number of root per explants and length of root were recorded 30 days after incubation in rooting medium. When the plantlets became 4-8 $\mathrm{cm}$ in length with 3-6 well-developed leaves and roots, the plantlets were removed from conical flasks. The roots were gently washed out with tap water. Plantlets were then individually transplanted to pots containing a mixture of ground soil and cowdung in the ratio of 1:1. Immediately after transplantation, the plants along with pots were covered with moist polythene bags to prevent desiccation. To reduce sudden shock, the pots were kept in the controlled environment in growth room for 7 days. Then the polythene bags were removed and the plantlets were kept in glasshouse. After 2 months when the plantlets attained a height of about $20-25 \mathrm{~cm}$, they were transferred to the field.

\section{RESULTS AND DISCUSSION}

\section{Colour changes of explant}

The colour of shoot tip explants showed creamy white appearance at first sight and gradually became brown to light green, green and finally dark green within 15-30 days on MS media supplemented with different concentrations of BAP (Plate a). The colour change of inoculated explants showed clear variation among the cultivers in the same treatment probably due to the genetic variation.

\section{Regeneration of single shoot}

At first subculture, it was observed that all the varieties developed single shoot in all the treatments except the control that failed to regenerate shoot in all cultivers (Table 1). Khanam et al. (1996); Rabbani et al. (1996) also reported the same results in case of control. Number of days required for single shoot regeneration varied with the concentrations of BAP and cultivars of banana. The highest percentage $(60 \%)$ of explant developed single shoot in case of 'Amritsagar' at $4.0 \mathrm{mg} / 1 \mathrm{BAP}$ within 10-15 days (Plate b). It was found that the percentage of single shoot regeneration was lower and the regeneration required longer time in the same dose in case of 'Sabri' than 'Amritsagar' and 'Seeded banana'. The results indicated that in all concentrations of BAP, single shoots were developed but the percentage of single shoot regeneration increased with increasing BAP concentrations in case of 'Sabri' and 'Anajee'. On the other hand, the single shoot formation was fluctuating at different concentrations of BAP in case of 'Amritsagar' and 'Seeded banana'. In all the cultivars shoots did not proliferate when BAP was omitted from the medium.

\section{Shoot multiplication from regenerated single shoot}

At second subculture, the response of different BAP treatments with MS media to shoot multiplication was found to be different and ranged from 20-80\%. In case of 'Amritsagar' the highest percentage (80\%) responded when it was inoculated on MS (Murasige and 
Skoog, 1962) media supplemented with $4.0 \mathrm{mg} / 1$ BAP (Table 2, Plate c). Number of plantlets/explants was also highest on MS (Murasige and Skoog, 1962) containing 4.0 mg/l BAP where 6-7 plantlets were developed per explant within 30 days. In 'Sabri' the response of multiple shoot formation was very low at $4.0 \mathrm{mg} / 1 \mathrm{BAP}$ concentration and the number of plantlets was 2-4 per explants. 'Seeded banana', responded negatively with different concentrations of BAP. So it was discontinued for further culture. Only $20 \%$ shoots of 'Anajee' developed multiple shoot in/on MS $+4.0 \mathrm{mg} / 1 \mathrm{BAP}$. It is clear from the result that the cultivar 'Amritsagar' responded very well in/ on MS $+4.0 \mathrm{mg} / 1 \mathrm{BAP}$.

Table 1. Effect of BAP on shoot regeneration at first subculture

\begin{tabular}{c|c|c|c|c|c|c|c|c}
\hline $\begin{array}{c}\text { Concentrations } \\
\text { of BAP (mg/l) }\end{array}$ & \multicolumn{4}{|c|}{$\begin{array}{c}\text { Percentage of explants developing } \\
\text { shoot }\end{array}$} & \multicolumn{4}{c}{$\begin{array}{c}\text { Days required for single shoot } \\
\text { development }\end{array}$} \\
\cline { 2 - 8 } & $\begin{array}{c}\text { Amrit } \\
\text { sagar }\end{array}$ & $\begin{array}{c}\text { Seeded } \\
\text { banana }\end{array}$ & Sabri & Anajee & $\begin{array}{c}\text { Amrit } \\
\text { sagar }\end{array}$ & $\begin{array}{c}\text { Seeded } \\
\text { banana }\end{array}$ & Sabri & Anajee \\
\hline 0.0 & $*$ & $*$ & $*$ & $*$ & $*$ & $*$ & $*$ & $*$ \\
2.0 & 40 & 30 & 20 & $*$ & $10-15$ & $15-20$ & $20-25$ & $*$ \\
4.0 & 60 & 50 & 20 & 20 & $10-15$ & $15-18$ & $15-20$ & $10-15$ \\
6.0 & 30 & 70 & 20 & 20 & $10-15$ & $10-18$ & $18-20$ & $8-12$ \\
8.0 & 50 & 60 & 40 & $*$ & $10-15$ & $10-15$ & $25-30$ & $*$ \\
\hline
\end{tabular}

Ten explants were cultured per treatment. * No response

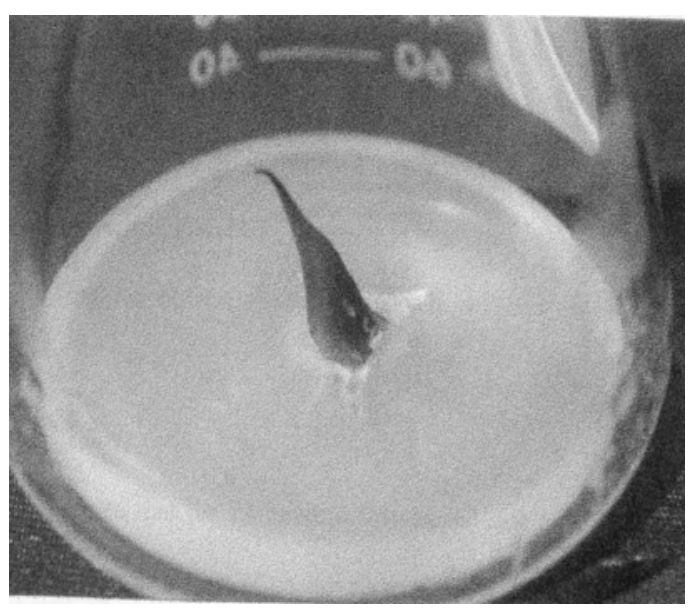

Plate a. A dark green shoot tip of 'Amritsagar' developed after 30 days of inoculation on MS media supplemented with $4.0 \mathrm{mg} / 1 \mathrm{BAP}$

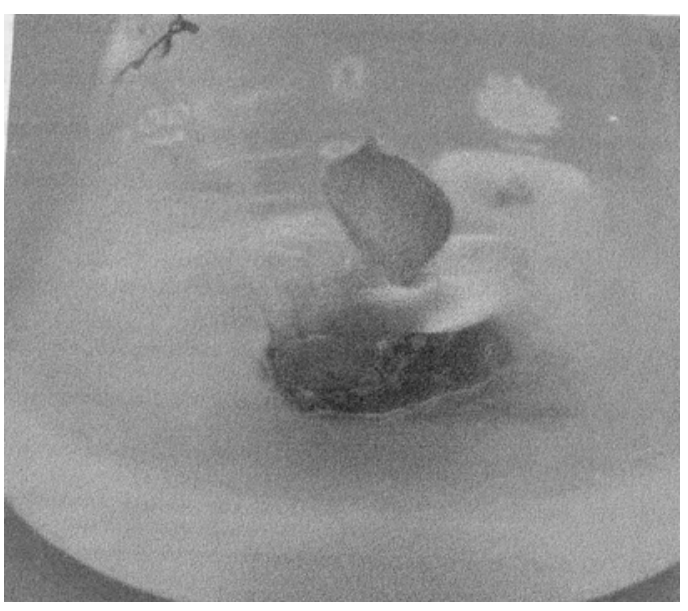

Plate b. A single shoot of Amritsagar developed at 4.0 mg/1 BAP after 30 days of culture

\section{Shoot multiplication of 'Amritsagar'}

Studies on in vitro proliferated shoots were continued for further shoot multiplication in 'Amritsagar' only. Due to poor performance, the other cultivars were omitted. The maximum number of plantlets/explant was developed in the medium containing 4.0 $\mathrm{mg} / 1 \mathrm{BAP}$ after both 15 and 30 days of culture (Plate $\mathrm{d}$ ). The average number of plantlets 
was also highest on MS $+4.0 \mathrm{mg} / 1 \mathrm{BAP}$ after 15 days with 2.6 plantlets/explant and 30 days with 6.0 plantlets/ explants (Table 3 ).

Table 2. Effect of BAP on shoot multiplication at second subculture

\begin{tabular}{c|c|c|c|c|c|c|c|c}
\hline $\begin{array}{c}\text { Concen- } \\
\text { trations of } \\
\text { BAP (mg/l) }\end{array}$ & \multicolumn{9}{|c|}{$\begin{array}{c}\text { Percentage of explants with multiple } \\
\text { shoot }\end{array}$} & \multicolumn{5}{c}{ Number of shoot/explant } \\
\cline { 2 - 9 } & $\begin{array}{c}\text { Amrit- } \\
\text { sagar }\end{array}$ & $\begin{array}{c}\text { Seeded } \\
\text { banana }\end{array}$ & Sabri & Anajee & $\begin{array}{c}\text { Amrit- } \\
\text { sagar }\end{array}$ & $\begin{array}{c}\text { Seeded } \\
\text { banana }\end{array}$ & Sabri & Anajee \\
\hline 0.0 & 0 & 0 & 0 & 0 & 0 & 0 & 0 & 0 \\
2.0 & 40 & $*$ & $*$ & $*$ & $3-4$ & $*$ & $*$ & $*$ \\
4.0 & 80 & $*$ & 40 & 20 & $6-7$ & $*$ & $2-4$ & 2 \\
6.0 & 60 & $*$ & 20 & $*$ & $3-4$ & $*$ & 2 & $*$ \\
8.0 & 20 & $*$ & $*$ & $*$ & $3-4$ & $*$ & $*$ & $*$ \\
\hline
\end{tabular}

Five explants were cultured per treatment. * No response

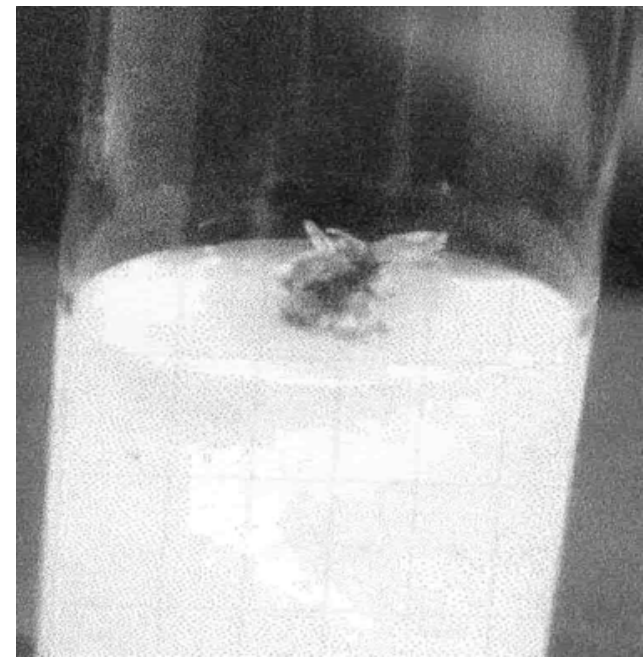

Plate c. Multiple shoots of Amritsagar regenerated at $4.0 \mathrm{mg} / 1 \mathrm{BAP}$ after 15 days of culture

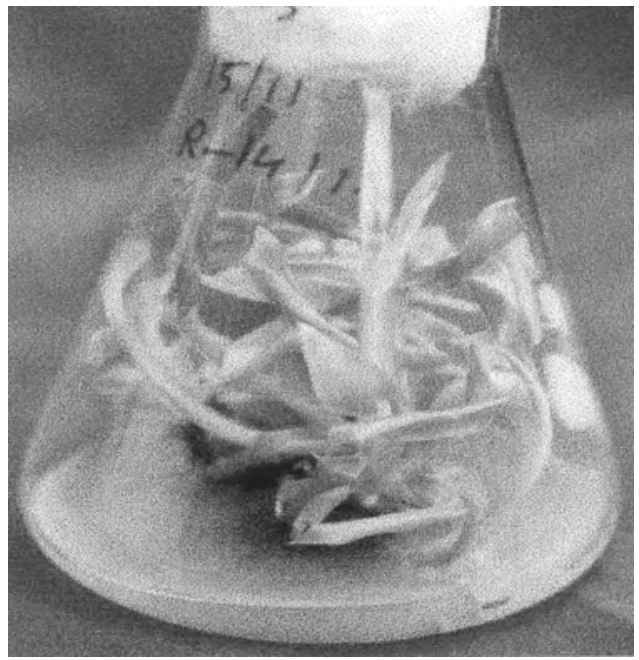

Plate d. Regenerated multiple shoot of Amritsagar in cluster at $4.0 \mathrm{mg} / 1 \mathrm{BAP}$ after 30 days of culture

\section{Root growth}

The regenerated shoots started to initiate root formation within 7 days after incubation on MS (Murasige and Skoog, 1962) medium supplemented with different levels of IBA (Table 4). As shoot formation was not occurred without BAP. Therefore in case of rooting no control treatment was continued as was also reported by Khanam et al. (1996). Among four concentrations of IBA used, $2.0 \mathrm{mg} / 1$ IBA was found to be more effective in rooting of the 'Amritsagar'. After 15 days, stunted or unsatisfactory roots were found at lower dose of IBA $(1.0 \mathrm{mg} / 1)$. The shoots cultured on MS $+2.0 \mathrm{mg} / 1$ IBA medium produced highest number of roots $(14.8)$, longest total root length was $(12.9 \mathrm{~cm})$ and average length 
of roots was $2.58 \mathrm{~cm}$, similar results were reported by Ghose (1993); Rabbani et al. (1996).

Table 3. Rate of shoot multiplication of Banana cv. "Amritsagar" as influenced by different concentrations of BAP

\begin{tabular}{c|c|ccc|c}
\hline \multirow{2}{*}{$\begin{array}{c}\text { Concentrations } \\
\text { of BAP }(\mathrm{mg} / \mathrm{I})\end{array}$} & \multirow{2}{*}{$\begin{array}{c}\text { Percent } \\
\text { responded }\end{array}$} & \multicolumn{4}{|c}{ Number of plantless/explant } \\
\cline { 3 - 6 } & & \multicolumn{2}{|c}{ 15 days after transfer } & \multicolumn{2}{c}{ 30 days after transfer } \\
\cline { 3 - 6 } & 0 & Highest no. & Average no. & Highest no. & Average no. \\
\hline 0.0 & 70 & 3 & 0 & 0 & 0 \\
2.0 & 100 & 4 & 1.8 & 4 & 2.4 \\
4.0 & 60 & 3 & 2.6 & 8 & 6.0 \\
6.0 & 60 & 2 & 2.0 & 6 & 4.0 \\
8.0 & & 1.4 & 5 & 3.2 \\
\hline
\end{tabular}

Table 4. Effect of IBA on in vitro rooting of banana shoots

\begin{tabular}{|c|c|c|c|c|}
\hline \multirow{2}{*}{$\begin{array}{l}\text { Concentrations } \\
\text { of IBA (mg/l) }\end{array}$} & \multirow{2}{*}{$\begin{array}{c}\text { Percentage of } \\
\text { shoots with } \\
\text { root }\end{array}$} & \multicolumn{2}{|c|}{ Average numbers of roots/plantlet } & \multirow{2}{*}{$\begin{array}{l}\text { Average root length }(\mathrm{cm}) \\
15 \text { days after inoculation }\end{array}$} \\
\hline & & $\begin{array}{l}7 \text { days after } \\
\text { inoculation }\end{array}$ & $\begin{array}{l}15 \text { days after } \\
\text { inoculation }\end{array}$ & \\
\hline 0.0 & 0 & 0 & 0 & 0 \\
\hline 1.0 & 100 & 6.0 & 7.8 & 1.44 \\
\hline 2.0 & 100 & 9.5 & 14.8 & 2.58 \\
\hline 3.0 & 100 & 6.2 & 11.2 & 1.34 \\
\hline 4.0 & 100 & 5.4 & 10.4 & 1.28 \\
\hline
\end{tabular}

Five explants were cultured per treatment

\section{Transplantation of in vitro regenerated plantlets on soil}

For hardening, the plantlets were covered with polythene bags to prevent desiccation and were placed in the growth room. After hardening for 7 days the polythene bags were removed and the plantlets were transferred to the open air under shade and kept for 7 days. Then the plantlets were again transferred into earthen pots and kept in glass house. All the plantlets were well established in the pots (Plate e).

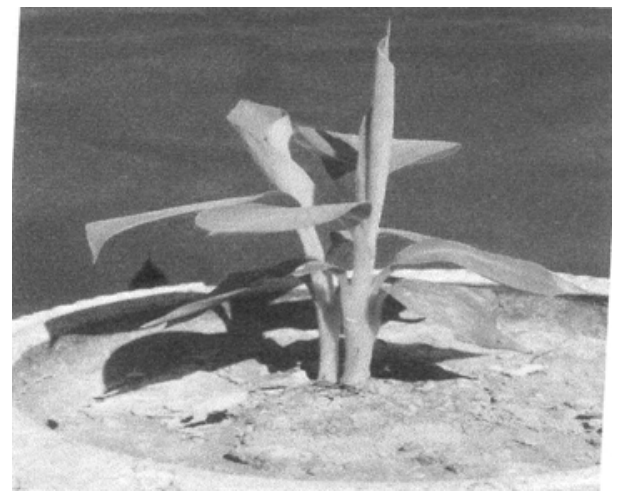

Plate e. Plantlets of Amritsagar established in pot after 15 days of transfer to soil 
Adequate moisture was supplied whenever needed and gradual exposure to air and light was given. In vitro derived plantlets were then ready for plantation in the field. All the plantlets survived and grew well. Cronauer and Krikorian (1984) found similar results. Haque (1988) used the mixture of ground soil, sandy soil and cow dung to stabilize regenerated plantlets in natural environment and Habib (1994) used a mixture of 1:1 of ground soil and cow dung for the same.

\section{CONCLUSION}

The present article describes a method of proliferation of shoot and formation of banana plantlets from shoot tip. This method has the potentiality to use as a tool of micropropagation of banana. Shoot tip derived plantlets are expected to be free from virus and other pathogens. However, further study is need for the confirmation of the in vitro shoots to be free from virus.

\section{REFERENCES}

Assche, Von. 1983. Technischeen conomische aspecten van de weefslteelt bij planten. Eindwerk, Kath. Univ. Leuven, Belgium: 1-134.

Bajaj, Y. P. S. 1986. Biotechnology of tree improvement for rapid propagation and biomass energy production. In: Bajaj, Y. P. S. (ed.) Biotechnology in Agriculture and Forestry. Tree I. Springer Verlag, Berlin, pp. 1-23.

Barker, W. G. and Steward, F. C. 1962. Growth and development of the banana plant. Ann. Bot., 26: 390-409.

Cronauer, S. S and Krikorian, A. D. 1984. Multiplication of Musa spp. from excised stem tips. Ann. Bo.t, 53(3): 329-328.

Evans, D. A., Sharp, W. R. and Flic, C. E. 1981. Plant regeneration from cell culture. In: Tanik, J. (ed). Horticultural Reviews, VoI. II. AVI publ, West Port Conn. pp. 214-314.

Ghose, S. P. 1993. Micropropagation of certain tropical horticultural crops. Southeast Asian Reggional Workshop of Commercial crops of the Tropics. Ho Chi Minh City, Vietnam, 7-12 February, 1992. pp. 25-26.

Habib, A. 1994. Mass propagation of Musa sapientum. Sagar and performance of different genotypes of Musa cavendishi (Grand Naine) in Bangladesh. M. S. Thesis, University of Dhaka. p. 53.

Haque, M. A. 1988. "Kolar Bagan" (in Bengali). Banana Research Project, Bangladesh Agricultural University, Mymensingh. p. 24.

Haris R. E. and Stevenson, J. H. 1979. Virus elimination and rapid propagation of grapes in-vitro. Proc. Int. Plant Crop. Soc. 29: 108.

Hwang, S. C., Chen, C. L., Lin, J. C. and Lin, H. L. 1984. Cultivation of banana using plantlets from meristem culture. Hort. Sci. 19: 231-233.

INIBAP. 1987. International Network for the Improvement of Banana and Plantain, Publication (October, 1987). Montpellier Cedex (France): pp. 8-9.

Khanam, D., Haque, M. A., Khan, M. A. and Quasem, A. 1996. In-vitro propagation of banana (Musa spp.). Plant Tissue Cult., 6(2) :89-94. 
Kunneman-Kooij. 1984. Inventarisatie van de toepassings mogelijkheden van weefselkweek CV de vegetative Vermeerdering Van houtige boomwekerijgewassen. Agriculture Univ. Wageningen, The Netherlands.

Murashige, T. and Skoog, F. 1962. A revised medium for rapid growth and bioassays with tobacco tissue cultures. Physiol Plant., 15(3): 473-497.

Pierik, K. L. M. 1975. Plantenteelt in Kweekbuizen. Thieeme, Zutphen, The Netharlands: 1-164.

Rabbani, M. G., Ali, M. H. and Mondal, M. F. 1996. Effect of BAP and IBA on micropogation of some banana cultivars. Bangladesh Hort., 25(1\&2): 47-52.

Stone, O. M. 1968. The elemination of four viruses from Carnation and Sweet Williams banana by meristem tip culture. Ann. Appl. Biol., 62: 119-122.

Thorpe, T. A. and Biondi, S. 1984. Conifers. pp. 435-460. In: Evans D. A, W. R. Sharp, P. V. Ammirato and Y. Yamada. (eds) Handbook of Plant Cell Culture, Vol. 2. Crop Species. Collier Macmillan Publishers. London. pp. 435-460.

Wong, W. C. 1986. In-vitro propagation of banana (Musa spp.): Initiation, proliferation and development of shoot tip cultures on defined media. Plant Cell, Tissue and Organ Culture, 6(2): 159-166. 